\title{
Mystical Experience and the Paraconsistent God
}

\author{
Benedikt Paul Göcke
}

Accepted: 25 February 2021/Published online: 24 August 2021

(C) The Author(s) 2021

Ayon Maharaj's Infinite Paths to Infinite Reality: Sri Ramakrishna and CrossCultural Philosophy of Religion (2018; henceforth, IPIR) is an excellent book. It contributes to cross-cultural philosophy of religion by showing not only that a profound philosophical dialogue between prima facie different philosophical traditions is possible and needed, but also by making a clear case that Western philosophy in fact can benefit enormously from Rāmakṛ̣na's philosophy of religion. In what follows, I focus on Rāmakrṣna's theory of the infinitude of God and bring it into further dialogue with my own position on both the paraconsistent nature of God and the possibility of veridical mystical experiences. In several papers, I have argued that ultimate reality is paraconsistent because this best explains how God could be the ultimate ground of empirical reality. I also argued that the conception of a paraconsistent God entails the truth of panentheism. In this response, I argue that a paraconsistent conception of God also explains the possibility that mystics subscribing to different worldviews can have veridical mystical experiences of ultimate reality that prima facie seem to contradict each other.

Benedikt Paul Göcke

benedikt.goecke@gmail.com

Ian Ramsey Centre for Science and Religion, Faculty of Theology and Religion, University of Oxford, Gibson Building, Radcliffe Observatory Quarter Woodstock Road, Oxford OX2 6GG, UK 


\section{The Paraconsistent God}

There is a fundamental distinction between qualitatively finite and qualitatively infinite entities. Qualitatively finite entities are those and only those entities that are subject to the law of contradiction; for every property $F$, a finite entity either exemplifies $F$, or not. Qualitatively infinite entities are not subject to the law of contradiction: Qualitatively infinite entities are those and only those entities that in respect to at least one property $F$ exemplify either both $F$ and not $F$, or neither $F$ nor not $F$. In the first case, the entity is a positive qualitatively infinite entity, in the second it is a negative qualitatively infinite entity.

\section{Panentheism and the Paraconsistent God}

It can be shown that the ultimate ground of empirical reality is a positive qualitatively infinite entity. It can also be shown that a paraconsistent conception of God entails panentheism. ${ }^{1}$ The argument for the paraconsistent nature of ultimate reality runs as follows:

(1) Neither the existence nor the essence of empirical reality is self-explanatory.

(2) If neither the existence nor the essence of empirical reality is selfexplanatory, then there is a single ultimate ground for both the existence and the essence of empirical reality.

(3) If there is a single ultimate ground for both the existence and the essence of empirical reality, then the ultimate ground of empirical reality is a positive qualitatively infinite entity.

Therefore:

(4) The ultimate ground of empirical reality is a positive qualitatively infinite entity.

The argument is deductively valid. If the premises are true, then the conclusion cannot fail to be true as well. Premise (1) is true: Neither the fact that empirical reality exists nor the fact that empirical reality has a particular essence can be used to explain why empirical reality exists at all or why it has a particular nature. Premise (2) is true: Based on the principle of sufficient reason and based on Ockham's Razor, it follows that there is an ultimate ground of the existence and essence of empirical reality. However, as Premise (3) states, this ultimate ground can only be a positive qualitatively infinite entity: The ultimate ground of empirical reality has to unite in its very own existence and essence all the features of empirical reality, that is, all properties $F$ of which it is true that either they or their complement are exemplified in empirical reality. If it did not unite all properties $F$ of which it is true that either they or their complement are exemplified in empirical reality, then features of empirical reality would exist of which the alleged

\footnotetext{
${ }^{1}$ Due to limitations in space, I can only provide a very brief justification of the conception of the paraconsistent God. For further analysis and argument in support of these claims, compare Göcke 2016, 2018, and 2019.
} 
ultimate ground of the existence and essence of all of empirical reality was not the ground. Suppose that some finite entities exist that are $G$ and some that are not $G$. Both their being $G$ and their being not $G$ are part of the determination of what is true about these entities. There is therefore something in virtue of which they are $G$ and not $G$. If the ultimate ground of empirical reality is not that in virtue of which some finite entities are both $G$ or not $G$, then it could not be the ground that some entities are $G$ and some are not $G$. This, however, would entail that it could not be the ultimate ground of empirical reality after all. Therefore, the ultimate ground of empirical reality is a positive paraconsistent entity. Based on the conclusion that the ultimate ground of empirical reality is paraconsistent, we can show that panentheism is true:

(5) If the ultimate ground of empirical reality is a positive qualitatively infinite entity, then the ultimate ground of empirical reality is neither identical to, nor distinct from, empirical reality.

(6) If the ultimate ground of empirical reality is neither identical to, nor distinct from, empirical reality, then panentheism is true.

Therefore:

(7) Panentheism is true.

Premise (5) is true: There is no feature of empirical reality, whether empirical reality is $F$ or not $F$, that is not also a feature of the ultimate ground of empirical reality. Therefore, the ultimate ground of reality is not to be distinguished from empirical reality: All things true about empirical reality are also true of ultimate reality. However, the ultimate ground of reality is also not identical to empirical reality: Empirical reality is qualitatively finite, whereas the ultimate ground of empirical reality is qualitatively infinite. Therefore, the ultimate ground of empirical reality is neither identical to, nor distinct from, empirical reality. That God is neither identical to, nor distinct from, the world, as Premise (6) states, is precisely the thesis of panentheism. On panentheism, God is a paraconsistent entity. On panentheism, empirical reality is in God, while God is also in empirical reality, without being exhausted by empirical reality. Therefore, panentheism is true.

\section{Maharaj's Critique of the Paraconsistent God}

Maharaj provides a thoughtful critique of my conception of the paraconsistent God. $\mathrm{He}$ argues that my account of God as a maximal qualitatively infinite entity is unsatisfying. A maximal infinite entity is an entity that exemplifies every property and its complement. Maharaj (IPIR 69) quotes me as follows: "If the predicate 'being evil' refers to a possible determination of an entity[,]...then my account entails that God is both evil and not evil" (Göcke 2016: 197fn47). He then argues as follows: "Does Göcke's evil-and-not-evil God correspond to the God of any of the major world religions? It seems not. Indeed, Göcke's maximally Infinite God hardly seems worthy of worship" (IPIR 69). I agree with Maharaj that a God that is both evil-and-not-evil would not be a proper object of worship. However, he is mistaken in thinking that I approve the antecedent of the material conditional. On my account 
it is not the case that "being evil" in fact denotes a first-order property exemplified by finite entities. But if there is no first-order property of being evil, then a maximal infinite entity does not exemplify both this property and its complement. What I had in mind when specifying the concept of a maximal infinite entity is the following: For every first-order property $F$ that is exemplified in empirical reality, God exemplifies $F$-and-not- $F$.

Maharaj criticizes my account of God as ultimate ground of empirical reality as follows:

Göcke limits_or finitizes - the Infinite God by defining Him only as the ontological ground of the universe. Sri Ramakrishna, I would argue, adopts a more fully paraconsistent approach to God than Göcke: If God is truly paraconsistent, then He must be both the ultimate ground of the universe and the transcendent nondual Brahman beyond the universe (IPIR 71; emphasis in the original).

I agree with Maharaj. However, on my account, to consider God as the paraconsistent ultimate ground of the universe is the conditio sine qua non of the soul's journey to recognize that God is also the non-dual Brahman and to recognize that panentheism is true. When Maharaj argues that my conception of God as ultimate ground of empirical reality is "narrow" and that "by defining God rigidly as the ultimate ground, Göcke robs God of His infinite majesty, love, and sovereignty" (IPIR 75), he overlooks the fact that the conception of the paraconsistent God as ultimate ground of empirical reality is only the first step on a path that dialectically leads to the recognition that God is all in all, neither distinct from, nor identical with, empirical reality. ${ }^{2}$ In fact, the conception of the paraconsistent God coheres well with Rāmakṛṣna's insight that "the Infinite Divine Reality is both personal and impersonal, both with and without form, both immanent in the universe and beyond it, and much more besides" (IPIR 33).

\section{Mystical Experience and the Paraconsistent God}

Based on the assumption that mystics with different worldviews have veridical mystical experiences of ultimate reality, another argument for the paraconsistent nature of ultimate reality can be formulated:

(1) If veridical mystical experience is possible, then it is possible that ultimate reality is an object of experience.

(2) If it is possible that ultimate reality is an object of experience, then it is possible to propositionalize the content of the respective experience of ultimate reality.

(3) It is possible to propositionalize the content of the respective experience of ultimate reality only if a particular conceptual framework is deployed.

(4) If a particular conceptual framework is deployed to propositionalize the content of the respective experience of ultimate reality, then the

${ }^{2}$ Compare Göcke 2012: 105-59 and 2014: 169-99. 
propositionalization of a veridical mystical experience depends on the worldview of the mystic in question.

(5) If the propositionalization of a veridical mystical experience depends on the worldview of the mystic in question, then a veridical mystical experience of ultimate reality is an experience of ultimate reality as seen from the point of view of the worldview in question.

(6) If a veridical mystical experience of ultimate reality is an experience of ultimate reality as seen from the point of view of a particular worldview, then there can be no contradiction between the propositionalizations of veridical mystical experiences the subjects of which have different worldviews.

(7) If there can be no contradiction between the propositionalizations of veridical mystical experiences the subjects of which follow different worldviews, then the nature of ultimate reality is not exhausted by the propositionalization of any veridical mystical experience.

(8) If the nature of ultimate reality is not exhausted by the propositionalization of any veridical mystical experience, then ultimate reality itself is such that different propositionalizations of veridical mystical experiences grasp different aspects of its nature.

(9) If ultimate reality itself is such that different propositionalizations of veridical mystical experiences grasp different aspects of its nature, then ultimate reality is paraconsistent.

(10) Veridical mystical experience is possible. Therefore:

(11) Ultimate reality is paraconsistent.

The argument is deductively valid. Premise (1) is true by definition: As Maharaj says, a mystical experience is "an experience which the subject takes to be an experience of ultimate reality" (IPIR 153fn1). Therefore, if veridical mystical experience is possible, then it is by definition possible that ultimate reality is an object of experience. Premise (2) is true: An experience the object of which is ultimate reality has a particular experiential content that can be the object of a propositional attitude, and therefore can be expressed as a proposition along the following lines: I experience that ultimate reality is such and such. If the experience is veridical, then the corresponding proposition is true. If the content of mystical experiences could not be expressed by a proposition, then no mystic could ever communicate what she has experienced. But there are numerous propositional claims made by mystics concerning the nature of ultimate reality that are based on their putative mystical experiences. However, as Premise (3) states, which proposition is formulated by the mystic as an adequate expression of the content of her experience depends on the concepts available to the mystic. The concepts we use are constitutive of the way we experience reality: I can only describe the content of my mystical experience as $F$ or not $F$, if I master the concept of $F$-ness. But, as Premise (4) states, the mastery of concepts and of the corresponding conceptual framework is always embedded in a larger worldview: It is, in effect, our worldviews that shape the way we propositionalize our experience. This, however, 
entails, as Premise (5) makes explicit, that a veridical mystical experience of ultimate reality adequately grasps what is true about ultimate reality if seen from the point of view of the worldview in question. If the propositionalization of a veridical mystical experience is conditioned upon the worldview of the mystic having this experience, though, then the truth of Premise (6) follows: There can be no contradiction between the propositionalizations of veridical mystical experiences the subjects of which follow different worldviews. Suppose $S_{1}$ follows worldview $W_{1}$ and has mystical experience $E_{1}$ which she formulates as $P_{1}$, whereas $S_{2}$ is an adherent of worldview $W_{2}$ and has mystical experience $E_{2}$ that is formulated as $P_{2}$. Although it is often argued that it could be the case that in such a scenario $P_{1}$ logically contradicts $P_{2}$, and that therefore at least one of the subjects is mistaken in taking her propositionalization of the corresponding mystical experience as an adequate statement regarding what is true about ultimate reality, this is a nonsequitur. ${ }^{3}$ It only follows that from the perspective of $W_{1}, S_{1}$ experiences ultimate reality as indicated by $P_{1}$, while seen from the point of view of $W_{2}, S_{2}$ experiences ultimate reality as formulated by $P_{2}$. There is no contradiction between $W_{1} \rightarrow P_{1}$ and $W_{2} \rightarrow P_{2}$. Because there is no contradiction here, it is possible that both $\mathrm{S}_{1}$ and $\mathrm{S}_{2}$ have veridical mystical experiences of what is true about ultimate reality. If it is possible that there are different veridical mystical experiences of what is true about ultimate reality that depend on the worldview of the mystic in question, then it follows in line with Premise (7) that the nature of ultimate reality is not exhausted by the propositionalization of any veridical mystical experience: No mystic can claim that her mystical experience completely grasps the nature of ultimate reality. The most she can claim is that against the background of her worldview, the nature of ultimate reality is adequately experienced having certain features. That is, each veridical mystical experience grasps what is true about ultimate reality if approached from the perspective of a particular worldview. However, if this is the case, then the truth of Premise (8) follows: If there are veridical mystical experiences, then the corresponding propositions formulated against the conceptual background of the mystic are true. If they are true, however, then ultimate reality itself is such that if seen from a particular point of view, it really is as it is experienced by the mystic. Because mystics with different worldviews have experienced the nature of ultimate reality in a variety of ways - as personal and impersonal, as formless, and as formed-it follows that ultimate reality in itself has to be such that it can adequately be experienced as personal or as impersonal, as formless, or as formed. This, in turn, as Premise (9) states, is only possible if ultimate reality itself is personal and impersonal, formless, and formed. Therefore, based on the assumption that Premise (10) is true, it follows that ultimate reality is

\footnotetext{
3 Compare Maharaj: "Although all theistic mystics agree that the ultimate reality which they experience is a loving personal God, some of these theistic mystics claim to have experienced God as Christ, others as Allah, and still others as Kṛșn, Kālī, or Śiva. In stark contrast to all of these theistic mystics, Advaitic mystics claim to have experienced their absolute identity with the impersonal nondual Brahman. Many Buddhist mystics, meanwhile, claim to have realized śūnyatā or nibbāna. According to the conflicting claims objection, since such claims about the nature of ultimate reality are mutually exclusive, the mystical experiences on which these claims are based are unreliable at best and delusive at worst" (IPIR 231-32).
} 
paraconsistent. As Rāmakṛ̣ṇa's says, "God is infinite, and the paths to God are infinite" (IPIR v).

Funding Open Access funding enabled and organized by Projekt DEAL.

Open Access This article is licensed under a Creative Commons Attribution 4.0 International License, which permits use, sharing, adaptation, distribution and reproduction in any medium or format, as long as you give appropriate credit to the original author(s) and the source, provide a link to the Creative Commons licence, and indicate if changes were made. The images or other third party material in this article are included in the article's Creative Commons licence, unless indicated otherwise in a credit line to the material. If material is not included in the article's Creative Commons licence and your intended use is not permitted by statutory regulation or exceeds the permitted use, you will need to obtain permission directly from the copyright holder. To view a copy of this licence, visit http:// creativecommons.org/licenses/by/4.0/.

\section{References}

Göcke, Benedikt Paul. 2012. Alles in Gott? Zur Aktualität des Panentheismus Karl Christian Friedrich Krauses. Regensburg: Friedrich Pustet.

Göcke, Benedikt Paul. 2014. A Theory of the Absolute. Basingstoke: Palgrave Macmillan.

Göcke, Benedikt Paul. 2016. "The Paraconsistent God." In Thomas Schärtl, Christian Tapp, and Veronika Wegener, eds., Rethinking the Concept of a Personal God: Classical Theism, Personal Theism, and Alternative Concepts of God, 177-99. Muenster: Aschendorff Verlag.

Göcke, Benedikt Paul. 2018. The Panentheism of Karl Christian Friedrich Krause (1781-1832): From Transcendental Philosophy to Metaphysics. Berlin: Peter Lang.

Göcke, Benedikt Paul. 2019. "The Quantitative and the Qualitative Infinity of God." In Benedikt Paul Göcke and Christian Tapp, eds., The Infinity of God: New Perspectives in Theology and Philosophy, 385-409. Indiana: University of Notre Dame Press.

Maharaj, Ayon. 2018. Infinite Paths to Infinite Reality: Sri Ramakrishna and Cross-Cultural Philosophy of Religion. New York: Oxford University Press.

\section{Publisher's Note}

Springer Nature remains neutral with regard to jurisdictional claims in published maps and institutional affiliations. 